\title{
NAUKA W SPOŁECZEŃSTWIE OPARTYM NA WIEDZY
}

\author{
Mirrors: Science and Knowlegde Society, pod red. Francesca Coniglionego \\ (numer specjalny „Axiomathes. An International Journal in Ontology \\ and Cognitive Systems” 19, 2009, nr 4, ss. 351-523)
}

Współczesny kształt uniwersytetu został uformowany w dobie Oświecenia na przełomie XVIII i XIX stulecia. Wtedy też uczelnie wyższe promujące narodową kulturę i będące promotorem demokratyzacji życia społecznego stały się kluczową instytucją państwa narodowego w Europie Zachodniej ${ }^{1}$. Wzajemne relacje pomiędzy społecznością naukową a otoczeniem zewnętrznym eksplorowane przez takie subdyscypliny naukowe, jak naukoznawstwo, historia czy socjologia nauki, były milcząco pojmowane jako relacje pomiędzy tak czy inaczej pojmowanym państwem narodowym.

Procesy globalizacyjne oraz aktywna polityka naukowa różnych agend Unii Europejskiej zmieniła w zasadniczy sposób otoczenie zewnętrzne nauki w poszczególnych krajach europejskich. Wstępem była tak zwana deklaracja paryska podpisana w maju 1998 r. przez ministrów Francji, Niemiec, Wielkiej Brytanii i Włoch, której celem było zapewnienie szkolnictwu wyższemu krajów członkowskich wyższej konkurencyjności w porównaniu ze szkolnictwem wyższym Ameryki i Australii. W 1999 r. podpisano deklarację bolońską, która zapoczątkowała proces unifikacji systemu wyższej edukacji nie tylko krajów sygnatariuszy, lecz i pozostałych krajów członkowskich, obejmujący między innymi wprowadzenie trójstopniowych studiów wyższych, punktów kredytowych, zachętę do mobilności studentów i pracowników naukowych oraz weryfikację jakości kształcenia. W marcu 2000 r. Rada Europejska przyjęła tak zwaną strategię lizbońska, wedle której gospodarka europejska winna do 2010 r. stać się „,najbardziej dynamiczną i konkurencyjną gospodarka na świecie”. Kluczową rolę w osiagnięciu tego celu przypisano uniwersytetom i szkolnictwu wyższemu, które miało dopomóc w stworzeniu ,gospodarki opartej na wiedzy". Te dwa równoległe procesy - proces boloński i deklaracja lizbońska, wpływając na politykę naukowa państw członkowskich Unii zmieniły (zmieniają) otoczenie społeczne, w jakim funkcjonuje nauka państw europejskich.

Zbadanie tych wzajemnych relacji jest przedmiotem zainteresowania projektu MIRRORS - ,Monitoring Ideas Regarding Research Organizations

${ }^{1}$ M. Kwiek, Narodziny uniwersytetu z ducha nowoczesności. Uwagi o transformacji instytucji $w$ epoce globalnej, „Principia. Pisma koncepcyjne z filozofii i socjologii teoretycznej”, t. 37-38, 2004, s. $45-62$. 
and Reasons in Science", sponsorowanego przez 7 program ramowy Unii Europejskiej (Nauka w społeczeństwie - 2007-1.1.1.1.: Revisiting the challenge of the interactions between science and politics in the European knowledge-based society). Zamierzeniem tego projektu - jak stwierdził jego kierownik Francesco Coniglione - jest analiza procesu decyzyjnego w zakresie polityki naukowej i technologii, a szczególnie w jaki sposób epistemologiczne, socjologiczne i technologiczne modele nauki wpływaja na wyznaczanie priorytetów w polityce naukowej poszczególnych krajów $\mathrm{UE}^{2}$. Końcowy raport projektu został wydany w 2010 r. pod redakcja F. Coniglionego, Through the Mirrors of Science. New Challenges for Knowledge-based Societies $\mathrm{w}$ wydawnictwie Ontos. Najbardziej interesująco poznawcze efekty dwuletnich badań zostały przedstawione w numerze specjalnym „Axiomathes. An International Journal in Ontology and Cognitive Systems" z grudnia 2009 r., zatytułowanym Mirrors: Science and Knowlegde Society (również zredagowanym przez F. Coniglionego). Prezentowane artykuły mieszczą się w ramach studiów nad nauką i technologią (STS - Science and Technology Studies), dyscypliny powstałej w drugiej połowie lat 70. (w 1975 r. powołano Society for Social Studies of Science) i integrującej historię, filozofię i socjologię nauki.

W celu jednak precyzyjniejszego określenia przedmiotu badań projektu F. Coniglionego warto posłużyć się klasyfikacją Evandra Agazziego, który wyróżnia otoczenie zewnątrzspołeczne i wewnątrzspołeczne nauki ${ }^{3}$. Otoczenie wewnątrzspołeczne składa się z systemów niespołecznych i społecznych działających w ramach danego społeczeństwa. Każdy z systemów społecznych charakteryzowany jest przez specyficzny cel lub funkcję społeczną. Celem społecznego systemu nauki jest „,rozwijanie obiektywnej, wiarygodnej wiedzy o rzeczywistości, tak by pogłębić rozumienie świata i wesprzeć ludzkie działania" ${ }^{4}$. Obok systemu nauki, autor wyróżnia system polityczny, ekonomiczny, militarny, religijny i tak dalej, zaś do systemów niespołecznych zalicza systemy biologiczne czy ekologiczne.

Otoczenie zewnątrzspołeczne dzieli się na międzynarodowe systemy niespołeczne, systemy naukowe i pozanaukowe systemy społeczne. Instytucje Unii Europejskiej w świetle tej klasyfikacji należałyby zarówno do międzynarodowych systemów naukowych, jak i międzynarodowych pozanaukowych systemów społecznych. Celem raportu jest zatem ustalenie wpływu tych międzynarodowych systemów społecznych (pozanaukowych) na politykę naukowa państw narodowych (a właściwie pewnych jego sektorów), czyli wpływu wewnątrzspołecznych systemów społecznych na system nauki w danym społeczeństwie/państwie narodowym.

Rzecz jednak w tym, że zarówno całe społeczeństwo, jak i jego poszczególne segmenty (w tym społeczność naukowa) moga być w różny sposób modelowane.

${ }^{2}$ F. Coniglione, Introduction: The Coming of the Knowledge Society and the Challenges for the Future of Europe, ,Axiomathes. An International Journal in Ontology and Cognitive Systems” 19, nr 4, 2009 , s. 365.

${ }^{3}$ E. Agazzi, Dobro, zto i nauka. Etyczny wymiar dziatalności naukowej, Warszawa 1997, s. 214-218.

${ }^{4}$ Ibidem, s. 215. 
Jedna z podstawowych dystynkcji jest podział teorii społecznych na antagonistyczne i solidarystyczne ${ }^{5}$. Zastosowanie tej dystynkcji pozwala zakreślić ogólną typologię związków pomiędzy społeczeństwem a nauką, pozwalająca osadzić prezentowane studia w pewnej tradycji rozważań.

W solidarystycznym modelu społeczeństwa i społeczności naukowej wytwory nauki harmonijnie wytwarzane przez całą społeczność naukową służyć maja całemu społeczeństwu. W tym ujęciu nie ma zatem zasadniczych sprzeczności pomiędzy nauką a społeczeństwem, a pojawiające się nieporozumienia mają bardziej charakter epistemologiczny niż społeczny.

W antagonistycznym modelu społeczeństwa (przy czym sprzeczności interesów moga samoistnie występować w życiu politycznym, gospodarczym czy kulturowym) i solidarystycznym modelu społeczności naukowej nauka służy dominującym klasom społecznym: władcom, właścicielom czy kapłanom (religijnym bądź świeckim). W takim ujęciu wszelkie konflikty w społeczności naukowej wnoszone sa do niej z zewnątrz, a remedium na ich uniknięcie czy chociaż osłabienie jest postulat jak największej autonomii społeczności naukowej uwalniający ją spod presji realizacji cudzych interesów społecznych.

Z kolei w antagonistycznym modelu społeczeństwa i samej społeczności naukowej samoistnie występujące $\mathrm{w}$ ramach społeczności naukowej konflikty interesów są osłabiane lub wzmacniane przez sprzeczności występujące w innych dziedzin życia społecznego. W takim ujęciu analizowanych układów społecznych postulat autonomizacji nauki pełni podwójną społeczną rolę: wzmacnia przed ingerencja innych klas społecznych, ale i wzmacnia wewnętrzną hierarchię w społeczności naukowej.

Prezentowane artykuły można podzielić na trzy grupy. Do pierwszej grupy należą ci autorzy (E. Coco, E. Montuschi, E. Viola), którzy w swoich artykułach nie odwołują się do jakiejś szczegółowej wizji społeczeństwa i środowiska naukowego, lecz prowadzą rozważania na bardzo ogólnym (lub szczegółowym) poziomie, który nie wymaga odwołania się do jakiejś konkretnej wizji społeczeństwa. Do drugiej grupy należą ci autorzy (F. Coniglione, G. Borbone, T. Charles, S. Nickes, S. Vasta), którzy odwołując się do określonej wizji społeczeństwa, zakładaja jego solidarystyczny model. Przyjmując takie założenia, Autorzy przedstawiają wdrażanie strategii lizbońskiej jako proces bezkonfliktowy, niepowodujący $\mathrm{w}$ zasadzie większych kontrowersji w samej społeczności naukowej i dyskusji wokół zmieniającego się miejsca nauki w społeczeństwie ${ }^{6}$. Trzecią grupę artykułów stanowią ujęcia tych Autorów

\footnotetext{
${ }^{5}$ Charakterystyka obu ujęć zob. np. S. Tang, Foundational Paradigms of Social Science, „Philosophy of the Social Science” 20, 2010, s. 19-22 oraz L. Nowak, U podstaw teorii socjalizmu, t. I: Dynamika wtadzy, Nakom, Poznań 1991, s. 9-14; zastosowanie tych podziałów do analizy społeczności naukowej w: idem, Science, That Is, Domination through Truth, w: P. Buczkowski, A. Klawiter (red.), The Theory of Ideology and Ideology of Theories (Poznan Studies in the Philosophy of the Sciences and the Humanities, t. 9), Rodopi, Amsterdam 1986, s. 106-122.

${ }^{6}$ A że tak być nie musi, pokazuje artykuł Ch. Lorenza, który dowodzi, że jednym z następstw wdrażania strategii lizbońskiej w Holandii był między innymi uwiąd autonomii akademickiej i umocnienie wpływów administracji uniwersyteckiej kosztem profesury, zob. Ch. Lorenz, Will the Universities Survive the European Integration? Higher Education Policies in the EU and in the Netherlands before and after the Bologna Declaration, „Sociologia Internationalis” 44, 2006, z. 1,
} 
(P. Hoyningen-Huene, G. Wolters), którzy dostrzegają pewne napięcia społeczne generowane przez naukę, bądź wokół niej, lecz nie wyjaśniają ich przez antagonistyczną naturę społeczeństwa (czy jego segmentów), lecz przez, w zasadzie nie do uniknięcia, nierówny rozwój gospodarczy poszczególnych państw lub poglądy przedstawicieli instytucji kościelnej wpływające na upowszechnienie treści badań naukowych.

We wstępnym artykule (Introduction: The Coming of the Knowledge Society and the Challenges for the Future of Europe) F. Coniglione zauważa, że ,idea przedustawnej zgody pomiędzy nauką i społeczeństwem była zawsze częścia »standardowego poglądu « (received view) odziedziczonego po greckim logosie i przekazanego nowożytnej nauce i oświeceniu"7. Założenie harmonii pomiędzy społeczeństwem a służącą mu nauką sprawiało, że naukowcy nie zawsze za celowe uważali objaśnianie i usprawiedliwianie swoich wyborów i badań szerszej publiczności. Jednakże $\mathrm{z}$ jednej strony - szerokie zastosowanie technologii w codziennym życiu oraz $\mathrm{z}$ - drugiej - dokonania filozofii nauki zmieniające obraz tego, jak rozwija się nauka i co czynią naukowcy, sprawiaja, że trzeba raz jeszcze przeanalizować relacje pomiędzy nauką a jej otoczeniem społecznym oraz proces decyzyjny przyjęty w polityce naukowej. F. Coniglione zakłada cztery wymiary naukowej praktyki przyjmowane $\mathrm{w}$ studiach nad nauką i technologią: treść teorii i odkryć naukowych (1), poznawcze i psychologiczne uposażenie podmiotów zaangażowanych w działalność naukową (2), mikrospołeczne interakcje (3) i makrospołeczne interakcje (kulturowe, ekonomiczne i polityczne) (4). Dwa pierwsze wymiary formuja ewidencyjny wymiar nauki, dwa następne - jej społeczny wymiar.

Obraz nauki przyjęty w standardowym poglądzie ujmował tę dziedzinę aktywności intelektualnej jako kumulatywną i ewolucjonistyczną, ignorując zmiany i historię nauki. Tymczasem za sprawa Thomasa Kuhna i Paula Feyerabenda stało się oczywiste, że nauka rozwija się w sposób antykumulatywistyczny i rewolucyjny: poprzednie teorie nie sa wchłaniane przez następne, lecz przezwyciężane i odrzucane. Z kolei mocny program socjologii wiedzy ujawnił społeczne (zewnętrzne) uwikłania rozwoju nauki, które często decydują o wyborze teorii. Zmusza to - zdaniem F. Coniglionego - raz jeszcze do przemyślenia związków pomiędzy nauką a społeczeństwem. Aby to jednak zrobić, potrzebna jest „,bardziej zrównoważona wizja nauki”, która nie może ,,ignorować znaczenia modelowania i idealizacji w badaniach naukowych" Przekonanie to, zdaniem F. Coniglionego, jest „,coraz bardziej akcentowane w ostatnich czasach w metanaukowej literaturze przedmiotu"10. Idealizacyjne pojmowanie statusu wytworów nauki pozwala bowiem na akceptację alternatywnych teorii naukowych, co wpływać ma na formułowanie alternatywnych wariantów polityki naukowej.

$\mathrm{Na}$ tak zarysowanym tle Autorzy tomu analizują poszczególne wymiary interakcji pomiędzy nauką a społeczeństwem. Giacomo Borbone w The Tacit

s. 123-151 oraz A. Lam, From Ivory Tower Traditionalists to Entrepreneurial Scientists'?: Academic Scientists in Fuzzy University-Industry Boundaries, ,,Social Studies of Science” 40, 2010, nr 2, s. 307-340.

7 F. Coniglione, Introduction..., s. 365.

8 Ibidem, s. 367.

${ }^{9}$ Ibidem.

${ }^{10}$ Ibidem. 
Epistemology of the GMO Debate: A Case Study bada postawy wobec genetycznie modyfikowanej żywności w dwóch romańskich krajach Europy: Hiszpanii i Włoszech. W Hiszpanii dominuje postawa otwarta i sprzyjająca, we Włoszech - nieufna i restrykcyjna. Zdaniem G. Borbonego, jest to zależne od milcząco przyjmowanej epistemologii, w skład której wchodzą: dogmat redukcjonizmu, zmiany i wytwarzania oraz denaturalizacji natury.

Zdaniem G. Borbonego, sceptycyzm wobec nauki bierze się z utożsamienie tego, co „,biologiczne”, z „,naturalnym”; z kolei to, co jest „,naturalne”, staje się „moralnie dobre”. Przeciwieństwem „,biologicznego” jest „,sztuczne”, utożsamiane dalej z ,„nienaturalnym”, a więc ,moralnie złym” ${ }^{11}$. W konkluzji swojego artykułu Autor podkreśla użyteczność idealizacyjnego ujęcia nauki, pozwalającego przezwyciężyć redukcjonistyczne podejście do nauki oraz wskazać na jej ograniczenia poznawcze ${ }^{12}$.

Sebastian Charles w artykule For a Humanism Amid Hypermodernity: From a Society of Knowledge to a Critical Knowledge of Society analizuje trzy koncepcje porządku społecznego: modernistyczny, postmodernistyczny i nadmodernistyczny. Według niego modernizm oparty był na nowym sposobie sprawowania władzy, zakładającym pojęcie paktu społecznego obejmującego niezbywalne prawa jednostki, a jego gwarancją miała być demokracja; nowym sposobie myślenia - opartym na rozumie i naukowych odkryciach, nowym sposobie produkcji opartym na rynku i nowym sposobie życia - opartym na indywidualizmie ${ }^{13}$. Postmodernizm jest natomiast modernizmem bez instytucjonalnych zabezpieczeń, ,które powstrzymywałyby jego podstawowe zasady przed pełnym rozwinięciem” ${ }^{14}$. Przedrostek ,nad-” oznacza społeczeństwo ,znaczone przez klimat braku umiaru, podrażnienia i ucieczki do przodu" ${ }^{15}$. S. Charles odwołuje się $\mathrm{w}$ tym miejscu swoich rozważań do Baumanowskiej kategorii „,płynnej rzeczywistości”. Zdaniem S. Charlesa, współczesna nauka i technologia poddana jest takiemu samemu klimatowi przesady i braku co inne segmenty społeczeństwa. Rola nauki w społeczeństwie hypermodernistycznym jest kluczowa, gdyż poszerza zakres indywidualnego wyboru i przyczynia się do indywidualizacji zaspokojenia potrzeb ${ }^{16}$. Tendencje te wzmacniaja potrzebe dialogu pomiędzy nauką a społeczeństwem, co z kolei jest przedmiotem rozważań Emanuele Coco (Dialogues, Notes, Essays, Letters and Diaries. An Analytical Proposal Regarding the Contribution of Literature to the Society of Knowledge). Zauważa on, że dialog taki nie był wcale warunkiem powstania nauki w antycznej Grecji i Babilonii. We współczesnym społeczeństwie jest on jednak koniecznością, gdyż przyczyniać się ma do korzyści płynących z rozwoju nauki dla całego społeczeństwa, jego gospodarki i poszczególnych obywateli.

\footnotetext{
${ }^{11}$ G. Borbone, The Tacit Epistemology of the GMO Debate: A Case Study, ,Axiomathes”, s. 380.

12 Ibidem, s. 378, 381 i 386. Zarówno F. Coniglione, jak i G. Borbone odwołują się do idei idealizacji rozwijanej w ramach poznańskiej szkoły metodologicznej, popularny wykład tej metody zob. L. Nowak, Wstep do idealizacyjnej teorii nauki, PWN, Poznań-Warszawa 1977.

${ }^{13}$ S. Charles, For a Humanism Amid Hypermodernity: From a Society of Knowledge to a Critical Knowledge of Society, ,Axiomathes”, s. 391.

${ }^{14}$ Ibidem, s. 394.

15 Ibidem, s. 392.

16 Ibidem, s. 397.
} 
O negatywnych następstwach braku dialogu pomiędzy ludźmi nauki a społeczeństwem (czy społeczeństwami, w których dokonuje się nierównomierny rozwój ekonomiczny) pisze Paul Hoyningen-Huene (Tension between Science and Society), zajmujący się zjawiskiem „drenażu mózgów”. Jak wiadomo, polega ono na migracji wykształconych osób z biednych krajów w poszukiwaniu pracy i możliwości zrobienia kariery do krajów zamożniejszych. W ten sposób nakłady na edukację wyższą biedniejszych krajów nie zwracają się, co jeszcze bardziej pogłębia ich zacofanie ekonomiczne. Autor odróżnia spontaniczny drenaż mózgów od zorganizowanego. Przykładem tego ostatniego było przyznanie przez Niemcy 10 tys. informatyków z Indii specjalnej ,zielonej karty”. W dyskusji, która na ten temat się rozwinęła, rozważano wady i zalety takiej decyzji dla gospodarki i społeczeństwa niemieckiego, lecz nikt nie rozważał jej następstw dla Indii.

Analiza procesu decyzyjnego w polityce naukowej jest przedmiotem artykułu Questions of Evidence in Evidence Based Policy autorstwa Eleonory Montuschi. Decyzje polityczne winny być oparte na twardych faktach. Tymczasem w nauce podkreśla się zależność danych empirycznych od teorii. Analogia ta występuje w procesie politycznym, w którym dane moga być rozmaicie interpretowane: ich status może być niepewny (wpływ promieniowania telefonów komórkowych na zdrowie), poddane różnym interpretacjom (globalne ocieplenia), źle rozumiane (pojęcie prawdopodobieństwa $\mathrm{w}$ diagnostyce medycznej), różnie oceniane (żywność genetycznie modyfikowana). W praktyce politycznej znajdujemy trzy postawy wobec niepewnych danych. Pierwsza, zaleca przyznanie decydującego głosu ekspertom, którzy po dyskusji podejmą odpowiednie decyzje, dwie następne postawy zalecają szukanie kompromisu wśród dostępnych danych lub ich interpretacji dostępnych w literaturze przedmiotu. Każde z tych rozwiązań podkreśla E. Montuschi - ma swoje wady i zalety ${ }^{17}$.

Thomas Nickles (Life at the Frontier: The Relevance of Heuristic Appraisal to Policy) w analizie następstw polityki naukowej korzysta z rozróżnienia na systemy nielinearne i linearne. Systemy linearne są stabilne, a ich funkcjonowanie nie jest w stanie zakłócić wpływ przypadkowych czynników, których następstwa da się łatwo przewidzieć. W systemach nielinearnych nawet nic nieznaczący czynnik może wywołać poważne zaburzenia w ich funkcjonowaniu. Jeżeli przyjmie się, że systemy społeczno-ekonomiczne są systemami nielinearnymi, to niewielka, mało kosztowna zmiana w polityce może przynieść pożądane znaczące efekty społeczne. Działa to również w przeciwną stronę nawet niewielka interwencja władzy jest ryzykowna, gdyż może przynieść niepożądane efekty społeczne ${ }^{18}$. Autor kończy swoje rozważania pewnymi praktycznymi konkluzjami. Filozofowie powinni wziąc aktywniejszy udział jako eksperci w dyskusjach nad zasadami polityki naukowej swoich krajów. W debacie tej filozofowie winni opowiadać się za społeczną solidarnością i odpowiedzialnością.

\footnotetext{
17 E. Montuschi, Questions of Evidence in Evidence Based Policy, „Axiomathes”, s. 437.

18 Th. Nickles, Life at the Frontier: The Relevance of Heuristic Appraisal to Policy, „Axiomathes”, s. 454 .
} 
Ten sam watek jest przedmiotem artykułu Enrica Violi (,Once Upon a Time” Philosophy of Science: STS, Science Policy and the Semantic View of Scientific Theories), który zauważa, że od uczestniczących w dyskusjach nad polityka naukowa filozofów nauki wymaga się zajęcia stanowiska w kwestiach etycznych, tak jakby etyka była wyłącznie przedmiotem zainteresowania filozofii, a nie nauki. Udział filozofów nauki w studiach nad nauką i technologią wymaga takiego przekształcenia tej dziedziny filozofii, aby jej wyniki mogły być przydatne $\mathrm{w}$ określaniu polityki naukowej. Wymaga to przyjęcia określonej wizji praktyki naukowej i jej wytworów. Zdaniem Autora, podstawy takiej dostarcza semantyczna teoria nauki, która zapewniać ma bardziej realistyczny i kompletny obraz samej praktyki naukowej oraz jej społecznych aspektów eksplorowanych przez mocny program socjologii wiedzy. Zdaniem E. Violi, ,jeżeli studia nad nauka i technologia chca uczestniczyć w doradztwie politycznym poprzez konstruowanie narracji praktyki naukowej użytecznych dla polityki naukowej zarówno pod względem empirycznej kompletności, jak i intelektualnej trafności, semantyczna teoria nauki jest właściwym kandydatem, spośród innych ujęć w filozofii nauki, aby zintegrować rozmaite metodologiczne składniki studiów nad nauką i technologia" ${ }^{19}$. Semantyczna teoria nauki zakładająca procedury idealizacji/abstrakcji i konkretyzacji jest w stanie wyjaśnić zjawisko niezdeterminowania teorii przez fakty, gdyż ten sam zbiór faktów może być wyjaśniany przez różne teorie. Wybór teorii uwarunkowany jest zatem również przez kontekst społeczny i historyczny, co stanowi podstawę formułowania różnych wariantów polityki naukowej.

Jednym z czynników kształtujących społeczno-kulturowe otoczenie teorii jest religia. Gereon Wolters $\mathrm{w}$ artykule The Epistemological Roots of Ecclesiastical Claims to Knowledge bada wpływ religii na postawy wobec nauki. Autor ten wyróżnia cztery możliwe relacje pomiędzy nauką a religią: konflikt, komplementarność, kooperację i niewspółmierność obu dziedzin. Autor wyróżnia dwa typy konfliktów: Galileuszowy, w którym religia i nauka utrzymuja różne stanowisko wobec faktów naukowych, oraz Freudowski, w którym nauka próbuje wyjaśnić zjawisko religijności czynnikami naturalnymi. Przykładem podejścia Freudowskiego ma być pogląd Marksa traktujący religię jako „opium dla ludu", samego Freuda ujmującego religię jako kolektywną neurozę czy Dawkinsa widzącego $\mathrm{w}$ religii produkt uboczny procesu ewolucji. Komplementarność obu dziedzin polegać ma na tym, że każda z nich odpowiada na różne ludzkie potrzeby. Kooperacja nauki z religia - której zwolennikiem jest obecny papież Benedykt XVI - polega na tym, że obie dziedziny wzajemnie się wspierają dla osiaggnięcia wspólnego dobra. Niewspółmierność religii i nauki zachodzi wtedy, gdy obie dziedziny mówią o fundamentalnie różnych rzeczach lub w fundamentalnie różny sposób, tak że porozumienie jest niemożliwe. W dalszej części artykułu Autor analizuje postawę Kościoła wobec teorii ewolucji, która przybierała postać konfliktu Galileuszowego (gdy Kościół kwestionował sam fakt ewolucji) bądź Freudowskiego (gdy Kościół odrzucał

${ }^{19}$ E. Viola, ,Once Upon a Time” Philosophy of Science: STS, Science Policy and the Semantic View of Scientific Theories, ,Axiomathes”, s. 466. 
wyjaśnienie religii $\mathrm{w}$ kategoriach teorii ewolucji) oraz eutanazji i homoseksualizmu. Zdaniem G. Woltersa, twierdzenie Kościoła o nieomylności otrzymanego od Boga Objawienia w postaci Biblii i twierdzenie o nieomylności urzędu nauczycielskiego sprawia, że Kościół w społeczeństwie demokratycznym zajmuje uprzywilejowaną epistemologicznie pozycję, co samo jest źródłem napięć i konfliktów.

Tymczasem zarówno społeczeństwo demokratyczne, jak i społeczność naukową cechować ma otwartość i podatność na krytykę. Cechy te sa przedmiotem analizy w artykule Salvatore Vasty, A New „Essential Tension” for Rationality and Culture. What Happens if Politics Tries to Encounter Science Again. Jego zdaniem, cechy te występuja zarówno w życiu politycznym, gdyż na nich oparta jest demokracja, jak i w społeczności naukowej. Demokratyczne cechy w nauce i polityce wzmacniają się nawzajem, gdyż zarówno demokracja polityczna, jak i współczesna nauka są produktem tego samego historycznego rozwoju społeczeństw europejskich.

Ogólnie otrzymaliśmy interesujący tom studiów, którego tematyka wykracza poza wąskie sformułowane cele projektu. Publikacja może zainteresować tych wszystkich, którzy nie tylko zajmuja się polityką naukową prowadzoną w krajach europejskich, lecz również dyscyplinami nauki składającymi się na multidyscyplinarne studia nad nauką i technologią.

dr hab. Krzysztof Brzechczyn

Profesor Uniwersytetu im. Adama Mickiewicza w Poznaniu

brzech@amu.edu.pl 